\title{
Effects of region of birth, educational level and age on late presentation among men who have sex with men newly diagnosed with HIV in a network of STI/HIV counselling and testing clinics in Spain
}

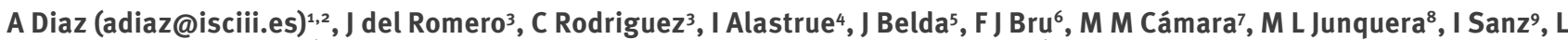
J Viloria ${ }^{10}$, L Gil ${ }^{11}$, E Martínez ${ }^{12}$, F Gual ${ }^{13}$, M C Landa ${ }^{14}$, I Pueyo ${ }^{15}$, J M Ureña ${ }^{16}$, B Martínez ${ }^{17}$, J A Varela ${ }^{18}$, A Polo ${ }^{19}$, M A Azpiri ${ }^{20}$, M Diez $^{1,2,21}$, for the EPI-VIH Study Group ${ }^{22}$

1. Área de Vigilancia del VIH y comportamientos de riesgo, Centro Nacional de Epidemiología, Instituto de Salud Carlos III, Madrid, Spain

2. Centro de Investigación Biomédica en Red de Epidemiología y Salud Pública (CIBERESP), Madrid, Spain

3. Centro Sanitario Sandoval, Madrid, Spain

4. Unidad de prevención de VIH e infecciones de transmisión sexual (UPS e ITS), Valencia, Spain

5. Unidad de prevención de VIH e infecciones de transmisión sexual (UPS e ITS), Alicante, Spain

6. Prevención ITS/SIDA, Instituto de Salud Pública, Ayuntamiento de Madrid, Madrid, Spain

7. Consulta de ETS, Servicio de enfermedades infecciosas, Hospital de Basurto, Bilbao, Spain

8. Consulta de ETS, Hospital Monte Naranco, Oviedo, Spain

9. Consulta de ETS. Plan de sida/ITS del País Vasco, San Sebastián, Spain

10. Sección de Vigilancia Epidemiológica, D.G. de Salud Pública, Cantabria, Spain

11. Centro de atención a las ITS (CAITS), Palma de Mallorca, Spain

12. Sección de Vigilancia Epidemiológica y Control de Enfermedades Transmisibles, D.G de Salud Pública y Consumo,

Consejería de Salud y Servicios Sociales, La Rioja, Spain

13. Servicio de Promoción y Educación para la Salud, DG Salud Pública, Murcia, Spain

14. COFES Iturrama, Navarra, Spain

15. Centro de ITS, Hospital Duque del Infantado, Sevilla, Spain

16. Centro de ITS y Orientación Sexual, Granada, Spain

17. Unidad de promoción y apoyo a la salud (UPAS), Malaga, Spain

18. Centro de ITS, Gijon, Spain

19. Unidad de prevención de VIH e infecciones de transmisión sexual (UPS e ITS), Castellón, Spain

20. Consulta de VIH, Ambulatorio Olaguibel, Comarca Araba- Osakidetza, Vitoria, Spain

21. Plan Nacional sobre el Sida, S.G. de Promoción de la Salud y Epidemiología, Ministerio de Sanidad, Servicios Sociales e Igualdad, Madrid, Spain

22. The members of the EPI-VIH Study Group are listed at the end of the article

Citation style for this article:

Diaz A, del Romero J, Rodriguez C, Alastrue I, Belda J, Bru FJ, Cámara MM, Junquera ML, Sanz I, Viloria LJ, Gil L, Martínez E, Gual F, Landa MC, Pueyo I, Ureña JM, Martínez B, Varela JA, Polo A, Azpiri MA, Diez M, for the EPI-VIH Study Group. Effects of region of birth, educational level and age on late presentation among men who have sex with men newly diagnosed with HIV in a network of STI/HIV counselling and testing clinics in Spain. Euro Surveill. 2015;20(14):pii=21088. Available online: http://www.eurosurveillance.org/ViewArticle.aspx?Articleld=21088

This paper analyses late presentation (LP) of HIV infection, and its determinants, among men who have sex with men (MSM) in Spain, newly diagnosed with HIV (2003-2011) in 15 sexually transmitted infection/HIV counselling and testing clinics. LP was defined as $<350$ CD4 cells/ $\mu$ L or AIDS. In total, 3,081 MSM were included (2,499 having CD4/AIDS); overall LP was $25.3 \%$. LP was higher in men older than 34 years, those not previously HIV-tested (adjusted odds ratio (aOR):3.1; $95 \%$ confidence intervals $(\mathrm{Cl}): 2.3-4.2)$, and those tested $>12$ months before diagnosis (12-24 months (aOR:1.4; 95\% Cl:1.0-2.0); > 24 months (aOR:2.2; 95\% Cl:1.7-3.0)). LP was less likely in MSM reporting a known HIV-infected partner as infection source or symptoms compatible with acute retroviral syndrome. 'Region of birth' interacted with 'educational level' and 'steady partner as infection source': only African and Latin-American MSM with low educational level were more likely to present late; Latin-American men attributing their infection to steady partner, but no other MSM, had LP more frequently. In Spain, HIV testing among MSM should be promoted, especially those > 34 years old and migrants with low educational level. The current recommendation that MSM be tested at least once a year is appropriate.

\section{Introduction}

Delayed diagnosis and treatment of HIV infection is a huge problem worldwide, with important individual and public health consequences. People presenting with an impaired immune system at diagnosis have higher rates of morbidity and mortality than those diagnosed earlier [1,2], and treating them is more costly [3]. Moreover, HIV-infected people unaware of their status may inadvertently spread HIV [4].

Different definitions have been used for late presentation of new HIV diagnoses [5], most of them based 
on different $\mathrm{CD}_{4}$ count levels at HIV diagnosis and/or simultaneous or recent diagnosis with acquired immunodeficiency syndrome (AIDS) [6-8]. To facilitate data comparisons, a consensus definition was proposed in Europe in 2010 and 2011 defining advanced disease (AD) as presenting a CD4 count below 200 cells/ $\mu \mathrm{L}$ or AIDS at diagnosis, and late presentation (LP) as having less than $350 / \mu \mathrm{L}$ or AIDS $[8,9]$.

In the European Union/European Economic Area (EU/ EEA) countries, nearly half (49.3\%) of new HIV diagnoses reported in $\mathbf{2 0 1 2}$ were late presenters (defined as fewer than $350 \mathrm{CD} 4$ cells/ $\mu \mathrm{L}$ at diagnosis), with a range of $35-66 \%$ across countries [10]. The proportion of LP was higher among heterosexuals (59.1\%) and people who inject drugs (PWID) (55.9\%) than among men who have sex with men (MSM), (38.4\%). In Spain, using the same definition, $48 \%$ of new HIV diagnoses reported to the national surveillance system that same year presented late; variations across exposure categories are similar, with MSM having the lowest proportion of LP in comparison to PWID and heterosexuals (39\%, 59\% and $65 \%$ respectively) [11].

In addition to the surveillance system, data on LP are available in Spain from the CoRIS cohort and the EPIVIH Network. CoRIS is a Spanish cohort of treatmentnaïve HIV patients which collects epidemiological/ clinical data in a broad setting [12]; LP in this cohort was $48.6 \%$ in the period 2004-2006 [2]. The EPI-VIH Network includes all sexually transmitted infections (STI) and HIV counselling and testing (HCT) clinics operating in the main Spanish cities; these are low threshold public facilities attending all key populations at higher risk for HIV [13,14]. Between 2003 and 2010, the proportion of LP in new HIV diagnoses in this network was $\mathbf{2 7 . 6 \%}$ [15], significantly lower than what was found in the comprehensive surveillance system [11].

Both in Spain (cohort and surveillance data) and elsewhere, several socio-demographic and epidemiological factors have been associated with LP, such as male sex, age, migration, low socio-economic status and HIV transmission mode $[2,5,16-18]$. Also, all the Spanish studies have showed that LP is less common in MSM than in other transmission categories, even after adjusting for other variables. However, little is known about factors affecting LP within this group. The objective of this paper is to analyse LP of HIV infection and its determinants among MSM newly diagnosed with HIV from 2003 to 2011 in the EPI-VIH Network.

\section{Methods}

All new HIV diagnoses among MSM testing for HIV between 2003 and 2011 in the EPI-VIH Network were included. The network in this period comprises 21 clinics located in the main Spanish cities: Alicante, Barcelona, Bilbao, Cartagena, Castellón, Gijón, Granada, Logroño, Madrid (two clinics), Málaga, Murcia, Oviedo, Palma de Mallorca, Pamplona, San Sebastián, Santander, Seville, Tenerife, Valencia and Vitoria. Fifteen of these clinics (excluding Castellon, Gijón, Granada, Malaga, Seville and Vitoria) systematically collect data on CD4 count after diagnosis. The clinics are public lowthreshold facilities, operating on a free basis, where every effort is made to maximise accessibility for key populations at higher risk. Participation in the EPI-VIH group is voluntary but, to our knowledge, all specialised STI/HCT clinics in Spain belong to this network.

Cases included in this analysis met the European case definition for new HIV diagnosis [19].

Epidemiological variables (age, sex, country of birth, educational level, date of HIV diagnosis, type of sexual partner reported as probable source of infection (casual partner, steady partner, known HIV-infected partner (steady/casual), commercial partner (sex worker/ client)), existence of a previous HIV test, date of previous HIV test, and clinical information (CD4 count, AIDS diagnoses, symptoms compatible with an acute retroviral syndrome, availability of health insurance card) were collected by the attending physicians using a standardised questionnaire.

LP was defined as having a CD4 count below 350 cells/ $\mu \mathrm{L}$ in the first determination after HIV diagnosis and/ or AIDS at diagnosis, following recent European recommendations $[8,9]$. The analyses were dealt with at the level of 'country/region of birth'; to assign 'region of birth', the World Health Organization Regional Office for Europe's classification was used. Frequency distributions for each variable and prevalence of LP, overall and stratified by different variables, were calculated. To evaluate the association between categorical variables, chi-squared tests were used; the associations between LP and individual explanatory variables were considered statistically significant at a $p$ value $<0.05$. Trends in LP over time were analysed using a joinpoint regression model. To identify factors associated with

\section{FIGURE 1}

Prevalence of late presentation among men who have sex with men newly diagnosed with HIV, by year of diagnosis, EPI-VIH Network, Spain, 2003-2011 $(n=2,499)$

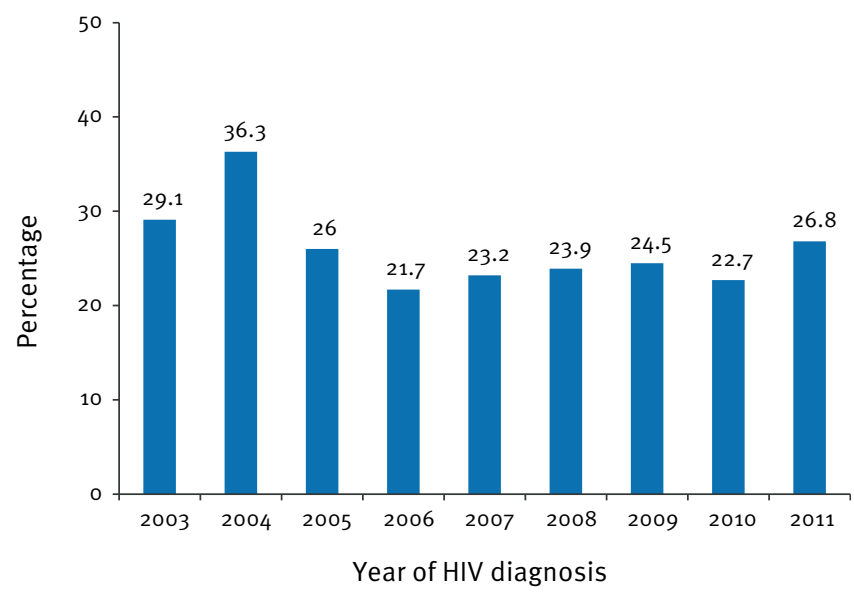


TABLE 1

Characteristics of men who have sex with men newly diagnosed with HIV, and prevalence of late and not late presentation in different subgroups, EPI-VIH Network, Spain, 2003-2011 $(\mathrm{n}=2,499)$

\begin{tabular}{|c|c|c|c|c|c|c|c|}
\hline \multirow[t]{2}{*}{ Variables } & \multicolumn{2}{|c|}{$\begin{array}{c}\text { Characteristics of MSM } \\
\text { newly diagnosed with } \\
\text { HIV }\end{array}$} & \multicolumn{2}{|c|}{$\begin{array}{c}\text { Prevalence } \\
\text { of late presentation }\end{array}$} & \multicolumn{2}{|c|}{$\begin{array}{c}\text { Prevalence } \\
\text { of not-late presentation }\end{array}$} & \multirow[t]{2}{*}{$\mathrm{p}$ value } \\
\hline & No & $\%$ & No & $\%$ & No & $\%$ & \\
\hline \multicolumn{7}{|l|}{ Age group (years) } & \multirow{6}{*}{0.00} \\
\hline$<25$ & 363 & 14.5 & 74 & 20.4 & 289 & 79.6 & \\
\hline $25-34$ & 1,232 & 49.3 & 285 & 23.1 & 947 & 76.9 & \\
\hline $35-44$ & 668 & 26.7 & 192 & 28.7 & 476 & 71.3 & \\
\hline$\geq 45$ & 208 & 8.3 & 75 & 36.1 & 133 & 63.9 & \\
\hline Unknown & 28 & 1.1 & 5 & 17.9 & 23 & 82.1 & \\
\hline \multicolumn{7}{|l|}{ Educational level } & \multirow{5}{*}{0.13} \\
\hline Illiterate/primary education & 375 & 15.0 & 107 & 28.5 & 268 & 71.5 & \\
\hline Secondary education & 1,023 & 40.9 & 257 & 25.1 & 766 & 74.9 & \\
\hline University education & 912 & 36.5 & 212 & 23.2 & 700 & 76.8 & \\
\hline Unknown & 189 & 7.6 & 55 & 29.1 & 134 & 70.9 & \\
\hline \multicolumn{7}{|l|}{ Region of birth } & \multirow{7}{*}{0.02} \\
\hline Spain & 1,617 & 64.7 & 384 & 23.7 & 1,233 & 76.3 & \\
\hline Western Europe & 78 & 3.1 & 20 & 25.6 & 58 & 74.4 & \\
\hline Central/Eastern Europe & 42 & 1.7 & 10 & 23.8 & 32 & 76.2 & \\
\hline Latin America & 713 & 28.5 & 205 & 28.8 & 508 & 71.2 & \\
\hline Africa & 17 & 0.7 & 8 & 47.1 & 9 & 52.9 & \\
\hline Unknown & 32 & 1.3 & 4 & 12.5 & 28 & 87.5 & \\
\hline \multicolumn{7}{|l|}{ Source of infection: steady partner } & \multirow{3}{*}{0.56} \\
\hline Yes & 938 & 37.5 & 243 & 25.9 & 695 & 74.1 & \\
\hline No & 1,561 & 62.5 & 388 & 24.9 & 1,173 & 75.1 & \\
\hline \multicolumn{7}{|l|}{ Source of infection: casual partner } & \multirow{3}{*}{0.46} \\
\hline Yes & 1,978 & 79.2 & 506 & 25.6 & 1,472 & 74.4 & \\
\hline No & 521 & 20.8 & 125 & 24.0 & 396 & 76.0 & \\
\hline \multicolumn{7}{|c|}{ Source of infection: commercial sexual contact } & \multirow{3}{*}{0.79} \\
\hline Yes & 153 & 6.1 & 40 & 26.1 & 113 & 73.9 & \\
\hline No & 2,346 & 93.9 & 591 & 25.2 & 1,755 & 74.8 & \\
\hline \multicolumn{7}{|c|}{ Source of infection: known HIV- infected partner } & \multirow{3}{*}{0.01} \\
\hline Yes & 263 & 10.5 & 50 & 19.0 & 213 & 81.0 & \\
\hline No & 2,236 & 89.5 & 581 & 26.0 & 1,655 & 74.0 & \\
\hline \multicolumn{7}{|l|}{ Acute retroviral syndrome } & \multirow{4}{*}{0.00} \\
\hline Yes & 361 & 14.4 & 55 & 15.2 & 306 & 84.8 & \\
\hline No & 735 & 29.4 & 220 & 29.9 & 515 & 70.1 & \\
\hline Unknown & 1,403 & 56.1 & 356 & 25.4 & 1,047 & 74.6 & \\
\hline \multicolumn{7}{|l|}{ Previous HIV-negative test } & \\
\hline No & 532 & 21.3 & 192 & 36.1 & 340 & 63.9 & \\
\hline Yes, «12 months before HIV diagnosis & 611 & 24.5 & 87 & 14.2 & 524 & 85.8 & م0 0 \\
\hline Yes, 12-24 months before HIV diagnosis & 557 & 22.3 & 114 & 20.5 & 443 & 79.5 & 0.00 \\
\hline Yes,> 24 months before HIV diagnosis & 779 & 31.2 & 236 & 30.3 & 543 & 69.7 & \\
\hline Yes, but date unknown & 20 & 0.8 & 2 & 10.0 & 18 & 90.0 & \\
\hline Health insurance card & & & & & & & \\
\hline Yes & 2,271 & 90.9 & 568 & 25.0 & 1,703 & 75.0 & 27 \\
\hline No & 103 & 4.1 & 24 & 23.3 & 79 & 76.7 & 0.21 \\
\hline Unknown & 125 & 5.0 & 39 & 31.2 & 86 & 68.8 & \\
\hline Total & 2,499 & 100 & 631 & 25.3 & 1,868 & 74.7 & \\
\hline
\end{tabular}

MSM: men who have sex with men. 


\section{TABLE 2}

Factors associated with late presentation among men who have sex with men newly diagnosed with HIV, univariate/ multivariate analysis, EPI-VIH Network, Spain, 2003-2011 $(\mathrm{n}=2,499)$

\begin{tabular}{|c|c|c|c|c|c|}
\hline \multirow{2}{*}{ Variables } & \multicolumn{2}{|c|}{$\begin{array}{c}\text { Univariate } \\
\text { analysis }\end{array}$} & \multicolumn{3}{|c|}{$\begin{array}{c}\text { Multivariate } \\
\text { analysis }\end{array}$} \\
\hline & OR & $95 \% \mathrm{Cl}$ & $\mathrm{aOR}$ & $95 \% \mathrm{Cl}$ & $p$ value \\
\hline \multicolumn{6}{|l|}{ Age group (years) } \\
\hline$<25$ & 0.8 & $0.6-1.1$ & 0.8 & $0.6-1.0$ & 0.08 \\
\hline $35-44$ & 1.3 & $1.1-1.7$ & 1.3 & $1.0-1.7$ & 0.02 \\
\hline$\geq 45$ & 1.8 & $1.4-2.6$ & 1.8 & $1.3-2.5$ & 0.00 \\
\hline \multicolumn{6}{|l|}{ Educational level (university education) $^{\mathrm{a}}$} \\
\hline Illiterate/primary education & 1.3 & $1.0-1.7$ & n.a. & n.a. & n.a. \\
\hline Secondary education & 1.1 & $0.9-1.4$ & n.a. & n.a. & n.a. \\
\hline Unknown & 1.4 & $0.9-1.9$ & n.a. & n.a. & n.a. \\
\hline \multicolumn{6}{|l|}{ Region of birth (Spain)a } \\
\hline Western Europe & 1.1 & $0.7-1.9$ & n.a. & n.a. & n.a. \\
\hline Central/eastern Europe & 1.0 & $0.5^{-2.1}$ & n.a. & n.a. & n.a. \\
\hline Latin America & 1.3 & $1.1-1.6$ & n.a. & n.a. & n.a. \\
\hline Africa & 2.9 & $1.1-7.5$ & n.a. & n.a. & n.a. \\
\hline \multicolumn{6}{|l|}{ Source of infection: steady partner (No) ${ }^{a}$} \\
\hline Yes & 1.1 & $0.9-1.3$ & n.a. & n.a. & n.a. \\
\hline \multicolumn{6}{|l|}{ Source of infection: casual partner (No) } \\
\hline Yes & 1.1 & $0.9-1.4$ & 1.0 & $0.7-1.3$ & 0.74 \\
\hline \multicolumn{6}{|c|}{ Source of infection: commercial sexual contact (No) } \\
\hline Yes & 1.1 & $0.7-1.5$ & 0.8 & $0.5-1.2$ & 0.22 \\
\hline \multicolumn{6}{|c|}{ Source of infection: known HIV-infected partner (No) } \\
\hline Yes & 0.7 & $0.5-0.9$ & 0.7 & $0.5-0.9$ & 0.02 \\
\hline \multicolumn{6}{|l|}{ Acute retroviral syndrome (No) } \\
\hline Yes & 0.4 & $0.3-0.6$ & 0.5 & $0.4-0.7$ & 0.00 \\
\hline \multicolumn{6}{|c|}{ Previous HIV-negative test (Yes, $\llcorner 12$ months before HIV diagnosis) } \\
\hline No & 3.4 & $2.6-4.5$ & 3.1 & $2.3-4.2$ & 0.00 \\
\hline Yes, $12-24$ months before HIV diagnosis & 1.6 & $1.1-2.1$ & 1.4 & $1.0-2.0$ & 0.03 \\
\hline Yes, >24 months before HIV diagnosis & 2.6 & $2.0-3.4$ & 2.2 & $1.7-3.0$ & 0.00 \\
\hline Yes, but date unknown & 0.7 & $0.2-3.0$ & 0.6 & $0.1-3.0$ & 0.54 \\
\hline \multicolumn{6}{|l|}{ Health insurance card (No) } \\
\hline Yes & 1.1 & $0.7-1.8$ & 1.2 & $0.7-2.1$ & 0.47 \\
\hline Unknown & 1.5 & $0.8-2.7$ & 1.3 & $0.6-2.5$ & 0.51 \\
\hline
\end{tabular}

aOR: adjusted odds ratio; $\mathrm{Cl}$ : confidence interval; MSM: men who have sex with men; n.a.: not applicable; OR: odds ratio.

Reference categories in brackets. Model adjusted by clinic of diagnosis.

a For convenience, adjusted odds ratio for interactions between these variables are shown in Figure 2.

LP, logistic regression models were fitted using a backward elimination procedure. Associations were measured using the odds ratio (OR) and its $95 \%$ confidence interval $(\mathrm{Cl})$. Data analyses were performed using the STATA statistical software package Version 13 (Stata Corporation, College Station, TX, US).

The EPI-VIH Network is an HIV sentinel surveillance system, and the database was registered in the Spanish Data Protection Agency (registry number 2080910068). No personal identifiers were collected.

\section{Results}

A total of 3,081 MSM newly diagnosed with HIV were identified during the study period. Of these 2,499 (81.1\%) had data on $\mathrm{CD}_{4}$ and/or AIDS diagnosis. The majority were born in Spain (64.7\%), were in the 25-34 year age group (49.3\%), and had secondary/university education (77.4\%). Almost one in six reported symptoms compatible with an acute retroviral syndrome, and $78.7 \%$ had been tested for HIV previously (Table 1). Median $\mathrm{CD}_{4}$ at presentation was 497 (interquartile range: $349-690)$. Overall, 631 MSM (25.3\%) met 


\section{FIGURE 2}

Interactions of 'region of birth' with 'educational level' (A) and with 'steady partner as probable source of infection' (B), multivariate analysis, EPI-VIH Network, Spain, 2003-2011 ( $\mathrm{n}=2,499)$

A Interaction between region of birth and educational level

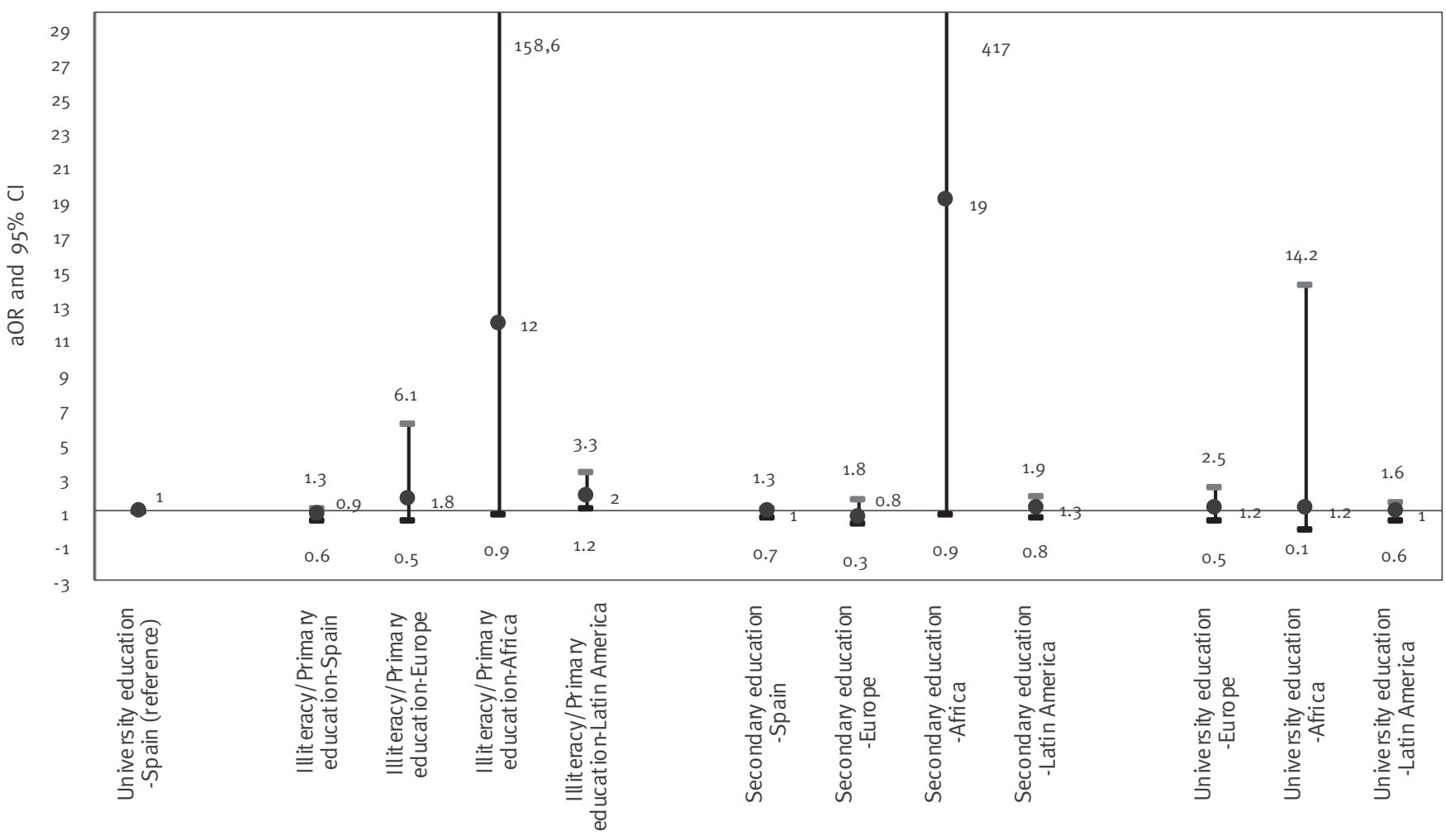

B Interaction between region of birth and steady partner as probable source of infection

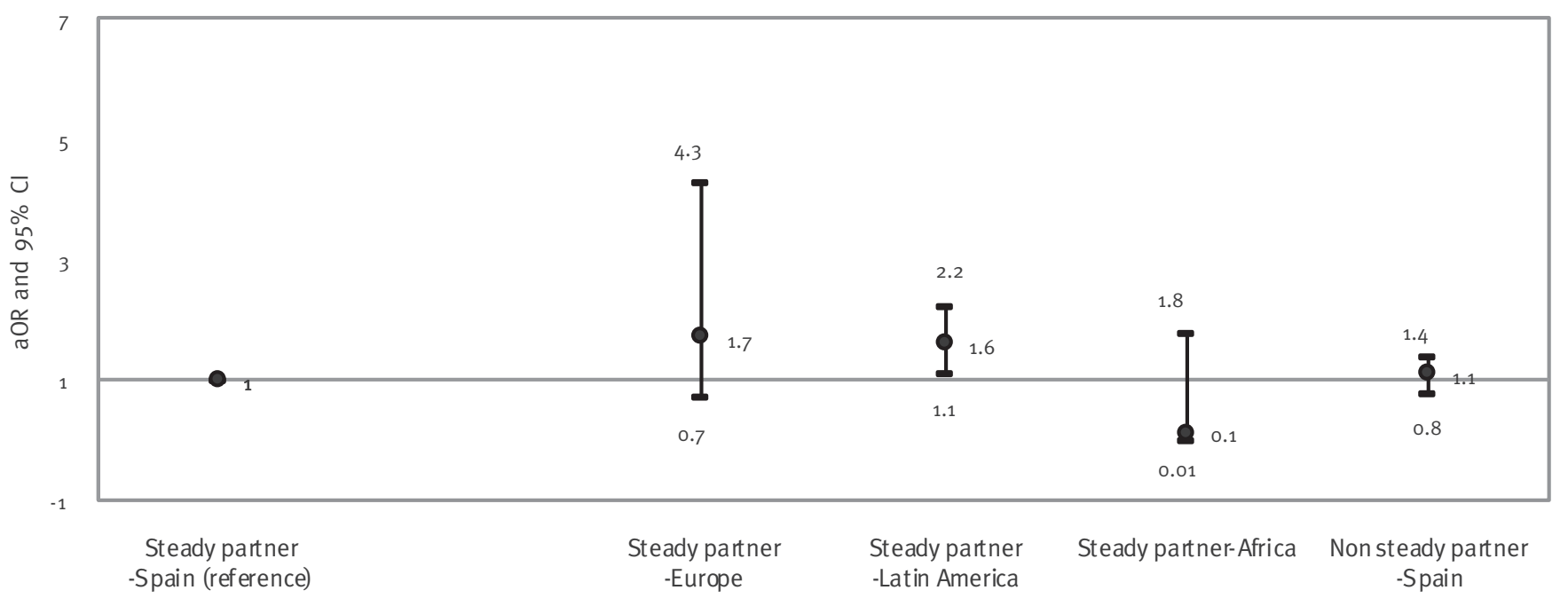

aOR: adjusted odds ratio; $\mathrm{Cl}$ : confidence interval.

Bars represent $95 \%$ confidence intervals.

Model adjusted by all variables shown in Table 2 plus clinic of diagnosis. 
the definition of LP (593 cases had fewer than 350 CD4 cells $/ \mu \mathrm{L}, 5$ presented AIDS at diagnosis and 33 had both). The proportion of LP increased with age, and was higher in men with a low educational level (28.5\%), in MSM born in Africa (47.1\%) or Latin America (countries of the American continent where Spanish or Portuguese is the main national language) (28.8\%), and among those without a previous HIV-negative test (36.1\%). Conversely, the prevalence of LP was lower in men attributing their infection to intercourse with a known HIV-infected partner (19\%) and those reporting an acute retroviral syndrome (15.2\%) (Table 1$)$. No trend was found in the prevalence of LP during the study period (Figure 1).

In the multivariate analysis, factors associated with LP were age over 34 years ( $35-44$ years: adjusted odds ratio (aOR): $1.3 ; 95 \% \mathrm{Cl}: 1.0-1.7 ; \mathrm{p}=0.02$ ) (> 44 years: aOR:1.8; 95\% Cl:1.3-2.5)), having no history of previous tests (aOR:3.1; 95\% Cl: 2.3-4.2) or having been tested more than 12 months before the diagnostic test ((12-24 months: aOR:1.4; 95\% Cl:1.0-2.0) (>24 months: aOR: $2.2 ; 95 \% \mathrm{Cl}: 1.7-3.0)$ ). Factors inversely associated with LP were reporting sexual contact with a known HIV-infected partner as the source of infection (aOR: $0.7 ; 95 \% \mathrm{Cl}: 0.5-0.9$ ) or symptoms compatible with an acute retroviral syndrome (aOR: 0.5; 95\% $\mathrm{Cl}: 0.4-0.7)$. Region of birth presented interactions with 'educational level' and with 'probable source of infection: steady partner': MSM born in Africa or Latin America, with low educational level (but not those with high educational level) had higher odds of presenting late, although, for Africans, results were on the edge of significance and confidence intervals were very wide due to the small sample size. Latin-American MSM attributing their infection to their steady partner (but not any other subgroup) were also more likely to present late (Table 2, Figure 2).

\section{Discussion}

This paper presents data on LP among MSM newly diagnosed with HIV in the EPI-VIH Network in Spain. Among MSM diagnosed in this network, LP is less common than in those diagnosed elsewhere, but presenting late is not evenly distributed, and the effect of region of birth on LP varies depending on the levels of two other variables.

Reducing diagnostic delay is a policy priority in Spain [20], and HIV testing is free of charge in all public facilities. Since 2009, HIV testing at least once a year has been recommended for MSM, and HIV testing guidelines that reinforce the importance of timely testing in this population have been issued recently [21]. In order to increase HIV testing availability and to facilitate anonymous testing, several regions have implemented testing in pharmacies [22] and others have made available rapid HIV tests in STI clinics and primary health care centres $[23,24]$. Testing programmes implemented by nongovernmental organisations are also playing an important role $[25,26]$.
The proportion of LP among MSM found in this study $(25.3 \%)$ is lower than what has been reported in this group in other Spanish settings: in a study performed in Barcelona from 2001 to 2009 the proportion was $47.7 \%$ [17], and in another analysis of data from 11 autonomous regions during the period 2007-2011, the figure was $39.1 \%$ [18], although in this case the definition of LP did not include AIDS. The prevalence in our study was also lower than the $34 \%$ reported in the United Kingdom in 2012 [27]. This finding is not surprising since the main purpose of the clinics belonging to the EPI-VIH Network is to be highly accessible to people with a high perceived risk for HIV, irrespective of their circumstances [15]. Also, MSM attending these clinics are probably very much aware of the importance of frequent testing: almost $80 \%$ of the participants in this study reported previous testing, while in the Spanish sample of the European MSM Internet Survey (EMISSpain) the proportion of men ever tested was 74\% [28]; furthermore, our clinics are located in the main cities, and EMIS-Spain showed that MSM living in big cities were more likely to have been tested for HIV [28].

Participants older than 34 years were found to be more likely to have LP, and the risk increased with increasing age. This finding is frequent in studies analysing LP $[16,18,29]$, and is consistent with results from a study conducted in England, Wales, and Northern Ireland in 2007, where MSM over 50 years of age were almost three times more likely to have a $\mathrm{CD}_{4}$ count of less than 350 cells/ $\mu \mathrm{L}$ at HIV diagnosis [30].

Low educational level [2] and migrant status $[17,18]$ have been described as predictors of LP in Spain, and poor education and little knowledge about HIV were also associated with being untested in an online Norwegian sample of MSM [31]. In our study, there was an interaction between education and migrant status, so that Latin-American and African MSM with low educational level (but not those from the same regions with high educational level or men from other regions) were more likely to present late. These results might reflect factors, such as lack of knowledge about HIV infection, lack of access to HIV diagnostics in their country of birth or lack of knowledge about HIV testing policies/ facilities in Spain, operating mainly in less educated migrants. In EMIS-Spain, MSM with low to middle educational level or lesser knowledge about HIV/STI, and those who were not confident about accessing HIV testing were more likely never to have been tested for HIV although, surprisingly, Spaniards were less likely than migrants to have been tested [28]; the likely explanation for this finding is that, in this particular study, most participating migrants were Latin-American with better educational level than their Spanish counterparts.

The fact that Latin-American MSM who attribute their HIV infection to their steady partners are at greater risk of LP warrants further investigation and suggests that emotional factors have to be considered 
when analysing LP. In any case, Latin-American MSM living in Spain appear to be highly vulnerable to HIV. They are over-represented in new HIV diagnoses [11] and showed higher levels of risky behaviours in EMISSpain, despite being highly educated and very knowledgeable about HIV [32].

It seems logical that men experiencing symptoms compatible with an acute retroviral syndrome and those reporting a known HIV-infected partner as their probable source of infection would have sought HIV testing quickly and therefore be less likely to present late. It is less obvious why not having a health card had no effect on LP, but this is not so surprising in our setting because this card is not required to be tested for HIV. LP was inversely associated with repeat HIV testing, a finding also reported in Danish MSM [33]. Our results even show an upward gradient of risk for LP as the time lag between the previous negative HIV test and the diagnostic test increased, underlining the importance for MSM to follow the recommendation of testing at least yearly.

This study has some limitations. Most importantly, MSM attending the EPI-VIH Network are not representative of the Spanish MSM population, thus our results cannot be extrapolated to all MSM in the country; unfortunately, educational level and probable source of infection are not collected in the regular surveillance system, thus preventing replication of the same analysis with these data. Furthermore, many persons were involved in data collection, thus increasing the probability of introducing mistakes; nevertheless, the EPI-VIH Network has been operating for many years, participating clinicians are very experienced, and a standard questionnaire is used to collect data. Finally, some degree of misclassification might exist if someone newly infected with HIV and presenting a low CD4 count was classified as late presenter.

On the other hand, we believe that results from this study are important to define effective interventions to increase HIV testing in the MSM subgroup that is probably at highest risk of infection. The need to test for HIV at least yearly should be further disseminated among the MSM community, and efforts should be made to increase awareness about symptoms suggestive of an acute antiretroviral syndrome. In addition, measures aiming at improving early diagnosis in poorly educated Latin- American and African migrants are a priority; in these MSM subgroups better knowledge about their situation is also needed to determine the best way to assist them.

\section{Members of the EPI-VIH Study Group}

M Diez, A Diaz, I Herrando (Centro Nacional de Epidemiología, Madrid); P Nogueras, E Castro, MJ Jimenez (Centro de ETS y Orientación Sexual, Granada); B Martínez, MA García, L Godoy (Unidad de Promoción y Apoyo a la Salud, Málaga); I Pueyo, E Ruiz, C Redondo, C Martínez, D Sánchez (Centro de ETS, Sevilla); JA Varela, C López, L Otero (Unidad de ETS,
Gijón); ML Junquera, M Cuesta, F Vázquez, F Carreño (Unidad de ETS. Hospital Monte Naranco, Oviedo); FJ Bru, C Colomo, A Comunión, P Chacón (Prevención ITS/SIDA. Instituto de Salud Pública. Ayuntamiento de Madrid, Madrid); J Belda, E Fernández, T Zafra, S Colomina, E Galán (Unidad de prevención de VIH e Infecciones de Transmisión sexual (UPS e ITS), Alicante); Jl Alastrué, C Santos, T Tasa, A Juan, E Fernandez, E Domenech, L Mitjans ( Unidad de prevención de VIH e Infecciones de Transmisión sexual (UPS e ITS), Valencia); J Trullen, A Fenosa, A Polo, E Silvestre (Unidad de prevención de VIH e Infecciones de Transmisión sexual (UPS e ITS), Castellón); MM Cámara, J López de Munain, MN Aparicio, MA Aizpuru (Unidad ETS. Enfermedades Infeccionas. H. Basurto, Bilbao); I Sanz, X Camino (Plan del Sida del País Vasco. San Sebastián); LJ Viloria (Sección de Vigilancia Epidemiológica. Servicio de Salud Pública. Consejería de Sanidad. Santander), MC Fernández, M de Vierna, A Estébanez, D Alvarez, F del Rio (COF La Cagiga, Santander); J del Romero, C Rodríguez, T Puerta, P Clavo, S García, S del Corral, B Menéndez, MA Neila, N Jerez, M Raposo, J Ballesteros, M Vera (Centro Sanitario Sandoval, Servicio Madrileño de Salud, Madrid); F Gual (Unidad de Prevención y Educación Sanitaria sobre SIDA, Murcia); MC Landa, H Yagüe, P Sánchez, A Gaztambide, I Huarte, E Sesma, J Benito (COFES Iturrama, Pamplona); MA Azpiri (Consulta VIH. Ambulatorio Olaguibel. Comarca Araba-Osakidetza,Vitoria); E Martínez, L Metola, C Quiñones, E Ramalle, V Ibarra, JA Otero (Servicio de Epidemiología y Promoción de la Salud, Logroño).

\section{Acknowledgements}

This work has been supported with grants No. 36303/02, $36537 / 05$ and 36794/08 from FIPSE (Fundación para la Investigación y la Prevención del Sida en España). The authors wish to thank Kathy Fitch for the English review.

\section{Conflict of interest}

The authors declare that they have no conflicts of interest.

\section{Authors' contributions}

MD was the main study researcher. She supervised field work and data collection, wrote the statistical analysis plan and the final version of the manuscript. AD performed data collection and management, quality control and statistical analysis, and wrote the first version of the manuscript. JdR, CR, IA JB, FJB, MMC, MLJ, IS, LJV, LG, EM, FG, MCL, IP, JMU, BM, JAV, JT, MAA, and EPI-VIH Study Group: were the clinicians responsible for patient recruitment and follow-up in the participating centres. They all participated in development of the study protocol, collection of epidemiological and clinical data, and critical review of all versions of the manuscript. All authors have seen and approved the final manuscript.

\section{References}

1. Sabin CA, Smith CJ, Gumley H, Murphy G, Lampe FC, Phillips AN, et al. Late presenters in the era of highly active antiretroviral therapy: uptake of and responses to antiretroviral therapy. AIDS. 2004;18(16):2145-51. http://dx.doi. org/10.1097/00002030-200411050-00006 PMID:15577647

2. Sobrino-Vegas P, García-San Miguel L, Caro-Murillo AM, Miró JM, Viciana P, Tural C, et al.CoRIS. Delayed diagnosis of HIV infection in a multicenter cohort: prevalence, risk factors, response to HAART and impact on mortality. Curr HIV Res. 2009;7(2):224-30. http://dx.doi. org/10.2174/157016209787581535 PMID:19275591

3. Krentz HB, Auld MC, Gill MJ. The high cost of medical care for patients who present late (CD4 $<200$ cells/microL) with HIV 
infection. HIV Med. 2004;5(2):93-8. http://dx.doi.org/10.1111/ j.1468-1293.2004.00193.x PMID:15012648

4. Marks G, Crepaz N, Janssen RS. Estimating sexual transmission of HIV from persons aware and unaware that they are infected with the virus in the USA. AIDS. 2006;20(10):144750. http://dx.doi.org/10.1097/01.aids.0000233579.79714.8d PMID:16791020

5. Mukolo A, Villegas R, Aliyu M, Wallston KA. Predictors of late presentation for HIV diagnosis: a literature review and suggested way forward. AIDS Behav. 2013;17(1):5-30. http:// dx.doi.org/10.1007/s10461-011-0097-6 PMID:22218723

6. Girardi E, Sabin CA, Monforte AD. Late diagnosis of HIV infection: epidemiological features, consequences and strategies to encourage earlier testing. J Acquir Immune Defic Syndr. 2007;46(Suppl 1):S3-8. http://dx.doi.org/10.1097/01. qai.0000286597.57066.2b PMID:17713423

7. Hall HI, Halverson J, Wilson DP, Suligoi B, Diez M, Le Vu S, et al. Late diagnosis and entry to care after diagnosis of human immunodeficiency virus infection: a country comparison. PLoS ONE. 2013;8(11):e77763. http://dx.doi.org/10.1371/journal. pone.0077763 PMID:24223724

8. Sabin CA, Schwenk A, Johnson MA, Gazzard B, Fisher M, Walsh J, et al.; UK Collaborative HIV Cohort (UK CHIC) Steering Committee. Late diagnosis in the HAART era: proposed common definitions and associations with mortality. AIDS. 2010;24(5):723-7. PMID:20057312

9. Antinori A, Coenen T, Costagiola D, Dedes N, Ellefson M, Gatell J, et al.; European Late Presenter Consensus Working Group. Late presentation of HIV infection: a consensus definition. HIV Med. 2011;12(1):61-4. http://dx.doi.org/10.1111/j.1468 1293.2010.00857.x PMID:20561080

10. European Centre for Disease Prevention and Control/WHO Regional Office for Europe. HIV/AIDS surveillance in Europe 2012. Stockholm: European Centre for Disease Prevention and Control.2013.

11. Área de Vigilancia de VIH y Conductas de Riesgo. Vigilancia Epidemiológica del VIH/sida en España: Sistema de Información sobre Nuevos Diagnósticos de VIH y Registro Nacional de Casos de Sida.[Epidemiological surveillance of HIV/AIDS in Spain: Information system on new HIV diagnoses and national AIDS case registry]. Madrid: Plan Nacional sobre el Sida - S.G. de Promoción de la Salud y Epidemiología / Centro Nacional de Epidemiología - ISCIII. 2013. Spanish. Available from: http://www.msssi.gob.es/ ciudadanos/enfLesiones/enfTransmisibles/sida/vigilancia/ InformeVIHSida_Junio2013.pdf

12. Caro-Murillo AM, Castilla J, Pérez-Hoyos S, Miró JM, Podzamczer D, Rubio R, et al.; Grupo de trabajo de la Cohorte de la Red de Investigación en Sida (CoRIS). Cohorte RIS de pacientes con infección por VIH sin tratamiento antirretroviral previo (CoRIS): metodología y primeros resultados. [Spanish cohort of naïve HIV-infected patients (CoRIS): rationale, organization and initial results.]. Spanish. Enferm Infecc Microbiol Clin. 2007;25(1):23-31. http://dx.doi. org/10.1157/13096749 PMID:17261243

13. Diaz A, Junquera ML, Esteban V, Martínez B, Pueyo I, Suarez J, et al.; STI Study Group and EPI-VIH Group. HIV/STI co-infection among men who have sex with men in Spain. Euro Surveill. 2009;14(48):19426. PMID:20003899

14. Diez M, Bleda MJ, Varela JA, Ordoñana JR, Azpiri MA, Vall M, et al. Trends in HIV testing, prevalence among first-time testers, and incidence in most-at-risk populations in Spain: the EPI-VIH Study, 2000 to 2009. Euro Surveill. 2014;19(47):pii=20971

15. Alastrué Loscos I, Diaz Franco A, Santos Rubio C, Juan Corrons A. ¿Son efectivos los centros especificos de VIH/ITS para disminuir el retraso del diagnóstico en la infección por el virus de la inmunodeficiencia humana? Enferm Infecc Microbiol Clin. 2014;32(10):689-90. http://dx.doi.org/10.1016/j. eimc.2014.04.004

16. Cevallos García C, Verdejo Ortés J, Martínez Rodríguez S, Izarra Pérez C. Retraso diagnóstico y enfermedad avanzada en la infección por el virus de la inmunodeficiencia humana en la Comunidad de Madrid (2007-2011). Rev Esp Salud Publica. 2012;86(1):37-47. http://dx.doi.org/10.1590/S113557272012000100004 PMID:22991028

17. de Olalla PG, Manzardo C, Sambeat MA, Ocaña I, Knobel $H$, Humet V, et al. HIV Surveillance Group. Epidemiological characteristics and predictors of late presentation of HIV infection in Barcelona (Spain) during the period 2001-2009. AIDS Res Ther. 2011;8(1):22. http://dx.doi.org/10.1186/1742 6405-8-22 PMID:21729332

18. Oliva J, Díez M, Galindo S, Cevallos C, Izquierdo A, Cereijo J, et al. Predictors of advanced disease and late presentation in new HIV diagnoses reported to the surveillance system in Spain. Gac Sanit. 2014;28(2):116-22. http://dx.doi.org/10.1016/j. gaceta.2013.06.009 PMID:24365520
19. Commission decision of 28 April 2008 amending decision 2002/253/EC laying down case definitions for reporting communicable diseases to the Community network under Decision No 2119/98/EC of the European Parliament and of the Council. Official Journal of the European Union; 2008 6-18-2008.

20. Plan Multisectorial frente a la infección por VIH y el sida. España 2008-2012. [Strategy plan against HIV infection and AIDS. Spain 2008-2012]. Madrid: Ministerio de Sanidad y Consumo, 2008. Spanish. Available from: http://www.msssi. gob.es/ciudadanos/enfLesiones/enfTransmisibles/sida/docs/ PMS200812.pdf

21. Ministerio de Sanidad Servicios Sociales e Igualdad. Guía de Recomendaciones para el diagnóstico Precoz del VIH en el ámbito sanitario. [HIV testing guidelines in clinical settings]. Madrid: Ministerio de Sanidad, Servicios Sociales e Igualdad, 2014. Spanish. Available from: http://www.msssi.gob.es/ ciudadanos/enfLesiones/enfTransmisibles/sida/docs/GUIA_ DXfinal_22Jul14.pdf

22. Gorostiza I, Elizondo López de Landache I, Braceras Izagirre L. Programa de cribado de VIH/sida en las oficinas de farmacia en la Comunidad Autónoma del País Vasco. Gac Sanit. 2013;27(2):164-6. http://dx.doi.org/10.1016/j. gaceta.2012.02.010 PMID:22554455

23. Cuesta Mdel M, López Mdel C, Nieto P, Junquera ML, Varela JA, Vázquez F. Implantación de una prueba rápida de VIH en Asturias (España).[ Introduction of a rapid HIV test in Sexually Transmitted Infections Units.]. Enferm Infecc Microbiol Clin. 2012;30(4):189-91. http://dx.doi.org/10.1016/j. eimc.2011.10.005 PMID:22137372

24. Esteban-Vasallo MD, Morán-Arribas M, García-Riolobos C, Domínguez-Berjón MF, Rico-Bermejo J, Collado-González S, et al. Targeted rapid HIV testing in public primary care services in Madrid. Are we reaching the vulnerable populations? Int J Infect Dis. 2014;19:39-45. http://dx.doi.org/10.1016/j. ijid.2013.10.006 PMID:24269650

25. Meulbroek M, Ditzel E, Saz J, Taboada H, Pérez F, Pérez A, et al. BCN Checkpoint, a community-based centre for men who have sex with men in Barcelona, Catalonia, Spain, shows high efficiency in HIV detection and linkage to care. HIV Med. 2013;14(Suppl 3):25-8. http://dx.doi.org/10.1111/hiv.12054 PMID:24033899

26. Fernández-Balbuena S, de la Fuente L, Hoyos J, RosalesStatkus ME, Barrio G, Belza MJ, et al.; Madrid Rapid HIV testing Group. Highly visible street-based HIV rapid testing: is it an attractive option for a previously untested population? A cross sectional study. Sex Transm Infect. 2014;90(2):112-8. http:// dx.doi.org/10.1136/sextrans-2013-051234 PMID:24234073

27. Aghaizu A BA, Nardone A, Gill ON, Delpech VC \& contributors. HIV in the United Kingdom 2013 Report: data to end 2012. London: Public Health England. November 2013.

28. Fernández-Dávila P, Folch C, Ferrer L, Soriano R, Diez M, Casabona J. Who are the men who have sex with men in Spain that have never been tested for HIV? HIV Med. 2013:14(Suppl 3):44-8. http://dx.doi.org/10.1111/hiv.12060 PMID:24033904

29. Mocroft A, Lundgren JD, Sabin ML, Monforte A, Brockmeyer N, Casabona J, et al.; Collaboration of Observational HIV Epidemiological Research Europe (COHERE) study in EuroCoord. Risk factors and outcomes for late presentation for HIVpositive persons in Europe: results from the Collaboration of Observational HIV Epidemiological Research Europe Study (COHERE). PLoS Med. 2013;10(9):e1001510. http://dx.doi. org/10.1371/journal.pmed.1001510 PMID:24137103

30. Smith RD, Delpech VC, Brown AE, Rice BD. HIV transmission and high rates of late diagnoses among adults aged 50 years and over. AIDS. 2010;24(13):2109-15. http://dx.doi. org/10.1097/QAD.ob013e32833C7b9c PMID:20616697

31. Berg RC. Predictors of never testing for HIV among a national online sample of men who have sex with men in Norway. Scand J Public Health. 2013;41(4):398-404. http://dx.doi. org/10.1177/1403494813483216 PMID:23567644

32. Soriano R, Fernández-Dávila P, Folch C, Ferrer L, Casabona J, Díez M. Sexual behaviour and risk among Latino MSM in Spain. Meeting "The Future of European Prevention among MSM"; Stockholm. November, 2011.

33. Helleberg M, Engsig FN, Kronborg G, Laursen AL, Pedersen G, Larsen 0 , et al. Late presenters, repeated testing, and missed opportunities in a Danish nationwide HIV cohort. Scand J Infect Dis. 2012;44(4):282-8. http://dx.doi.org/10.3109/00365548.20 11.626440 PMID:22066814 